\title{
Laws and Policies Pertaining to Women's Workers Rights and Legal Aid Services in India.
}

\author{
Shilpa B.P \\ Research Scholar, Alliance University, Assistant Professor SJRCL, Chandapura, Bangalore
}

\begin{abstract}
Social Justice is essential to maintain a sustainable peace as well as encouraging sustainable economic growth. Ensuring gender equality and protection of women's interest in Labour law it is a key ingredient to improving social justice. The working women's need equal treatment and special protection under the Law. In India many legislative provisions, along with Constitution gave a special protection to women. The Labour laws in India framed many laws for the protection of women's by providing protective health, safety, welfare measures according to International Labour Organization Standards. The working women's irrespective of any status approach free legal aid services in concerned authorities for any disputes arises in their work field. The Legal services Authorities Act of 1987, provided this opportunity to every woman in Legal aid services, not being an any rank the women in India can approach free legal aid services by approaching concerned legal services authorities for their litigations. The Legal Services Authorities Act of 1987 is providing this opportunity for women workers.
\end{abstract}

Keywords: Social Justice, Women, Labour Laws, ILO standards, Legal aid Services

\section{INTRODUCTION}

Social justice means the attainment of socio-economic equality. Labour laws play a vital role as instruments of social justice. The quantity and quality of Labour are both a cause and consequence of economic development. Women constitute almost half of such Labour working in various capacities in many areas. The ILO formed in 1919, has been a pioneer in securing social security of Labour by organizing a various convention. Similarly, in Indian constitution part IV DPSP gave a power to legislature to enact such laws to women safety and upliftment. The researcher focus presentation in 3 heads- 1 . Labour Laws regarding health safety and welfare of Women 2. Labour Laws regarding social security measures 3 . Legal aid services pertaining to women Workers.

\section{METHODOLOGY:}

The methodology which the author adopted is doctrinal the data collected by researcher is secondary resources Books, Articles, and web results.

The Ministry of Labour and Employment introduced four Bills in 2019 to amalgamate 29 Central Laws related to Labour Laws thereby simplifying and modernizing the labour regulations in a labour-intensive country. The bill regulates the code on wages, industrial relations, social security and occupational safety and health and working conditions. Which have been codified and enacted as- 1 . The Code on wages 2019, 2. The Industrial Relations Code 3. The Occupational Safety, Health and Working Conditions Code 2020 4. The Code on Social Security 2020

These Labour law provides for legislative framework which governs the relationship between the employees, the employees and employer, the right, liabilities and obligations of the workers and their obligations of the workers and their employer, and the disputes arising between them, health and welfare benefits, working conditions, safeguarding the interests of the workers and to make provisions for the wages, bonuses, provident funds, leaves, working hours, compensations, provisions for lay-offs and retrenchments and the like, formulations and functioning of trade unions. This list is however not exhaustive but an indication of the many areas which are covered under the term labour laws. If failure to do this measure by employee, and any dispute arises on this area the women employee can approach free legal services in concerned authorities.

1. Labour Laws regarding health, safety, and welfare of Women (Occupational safety, Health and working Conditions Code, 2020) Labour Laws providing welfare provisions to working Women's. The author discussed few Labour laws and welfare provisions under the code namely,

1.Factories Act - 1948 Sec. 22(2), 27,34,87 Mines Act 1952 Sec. 57(j) - Prohibition of employment in women in dangerous operation. In Pearson vs. Belgium Co.ltd the question was whether stationary parts of a machine can by cleaned by woman if the machine is in motion. It was held by the court that if the machinery is in motion even stationary parts of the machine cannot be cleaned by woman. 


\section{International Advanced Research Journal in Science, Engineering and Technology}

Vol. 8, Issue 10, October 2021

\section{DOI: $10.17148 /$ IARJSET.2021.81016}

2.Prohibition of Night Work: sec.66(1) of Factories Act, sec.46(1) of Mines Act, sec.25 of Plantation Labour Act 1951, sec. 25 Beedi and cigar workers (conditions and employment) Act 1966, laws provides woman shall be required to allowed to work in any factory between the hours of $6 \mathrm{am}$ and 7pm. Exception: but the state government may by notification in the official gazette, in respect of any factory or group or class or description of factories, vary the limits pertaining to night duties but no such variation shall authorise the employment of any woman between the hours of $10 \mathrm{pm}$ to $5 \mathrm{pm}$ 3. Creche facilities for women workers- Sec.48 FA Act, sec. 21 MA Act, Separate rest rooms and washrooms for women workers-Sec.19 of FA Act, Sec.20 MA Act 5. prohibition of sub-terrain work-Sec.46(1) MA Act 6. provide Information center to women in working premises.

General facilities: Maintain cleanliness and disposal of wastes and effluents, avoid overcrowding, Instruction boards, safety clothes, Sitting arrangements, medical facilities, Canteen facilities, Annual leave etc.

2.Social Security measures to Women's Workers. ( Code on Social Security 2020)

* The Maternity Benefit from Act-2017- maternity leave raise 12 weeks to 26 weeks, prenatal leave also increased 6 weeks to 2 months etc.

* The sexual harassment of Women at workplace (Prevention, Prohibition, and Redressal Act, 2013- after 16 years of vishaka Judgement, and ILO guidelines India has adopted this legislation. The aggrieved women who will get protection un, der the Act is extremely wide to cover all Women, irrespective of her age or employment status, whether in the organized or unorganized sectors, Public or private. It also covers clients, customers, and domestic workers in associate with these organization and sectors.

* The employees State Insurance Act 1948 provides insured women workers get sickness, disablement, dependents, medical benefits, and funeral expenses along with the insured men workers. It also covers maternity benefits in certain aspects. According to Act both employee and employer must contribute certain percentage of monthly wage to the insurance corporation that run dispensaries and hospitals in working class localities.

* National Rural Employment Guarantee Act 2005 the Act provides 100 days wage training program both skilled and unskilled workers for the development of living standards of rural India where most of the population resides.

3. Code on Wages 2020 The code provides common definition laws covered by this code. According to this code employer must pay wages not less than $50 \%$ of total remuneration of the workers.it covers laws namely,

* The Equal remuneration Act 1976 - parity in wages is one of the major components of service law of Jurisprudence. According to that if two workers are doing the same work, they should be paid equal wages. Without discrimination of any sex. In The people's Union for Democratic Rights v. UOI apex court by referring Equal Remuneration Act of 1976, held that irrespective of any gender workers are considered equal in the eyes of law based on that both are eligible to take equal remuneration with same work.

4. Legal Aid Services pertaining to Women Workers. According to Legal services Authorities Act of 1987, legal services include the rendering of any service in the conduct of any case or other legal proceedings before any court or other authority or tribunal and the giving of advice on any legal mater to provide free and competent legal services to the weaker section of the society. The Constitution of India, Art-39 A provides state to ensure justice based on equal opportunity by providing free legal aid services and make appropriate legislation to it.

According to Sec.12(c)(e) included women provides Industrial workman entitle to approach free legal services in concerned authorities. The nature of service providing under the Act includes- Awareness program, free litigation, providing free advocate to contest before the court. The Advocate who took case of anyone will get nominal amount by the government not by the client.

Under Legal Services Authorities Act, the National ,State, District Legal Services Authorities and Taluk, High Court, Supreme Court Legal services Committees providing nationwide Legal services under the Act .

\section{RESULTS AND DISCUSSION}

The benefit of laws enacted by the legislators many women workers filled a case before the court of law to resolve their disputes by seeking free legal services by the authorities and their own. Such cases are namely,

*M/s MacKinnon Mackenzie \& Co. Ltd v. Andrey D’Costa \& another (1987) I LL. J 536 in this case difference between remuneration between male and female stenographer was questioned before the court of law, the management contended that, there is mutual agreement between them for remuneration based on that remuneration was given, but court held that it violates the laws, and both are eligible to get remuneration without any discrimination

*In Shah v. Labour Court, Coimbatore AIR 1978 SC 12 the question was whether Sunday is to be counted in calculating the amount of Maternity benefit. The court held that in sub section (1),(3) and of sec.5 of maternity benefit Act the term week has to be taken to signify a cycle of seven days including Sundays.

*Sanjit Roy v State of Rajasthan (236) it was held that the person who provides labour or service to another is entitled to get at least minimum wage, and anything less than the minimum wage are else he can complain of violation of his fundamental right under Art.23 and ask the court to direct payment of minimum wages. 


\section{International Advanced Research Journal in Science, Engineering and Technology}

Vol. 8, Issue 10, October 2021

\section{DOI: 10.17148/IARJSET.2021.81016}

*Air India v Nargesh meerza (AIR 1981 SC 1929) The regulation 46 of Air India provides air hostess would retire from the service of the corporations upon attaining the age of 35 years, or on marriage, if it took place within four years of service or on first pregnancy, whichever occurred earlier. And regulation 47 says to terminate women employee managing director has discretion. The Supreme Court struck down the airline's regulations based on the violation of fundamental rights of Women employees and held this provision is unconstitutional and against to morality.

*Mrs.Sivanarul V State of Tamil Nadu and others (1985 II LLJ 133) The court held that the order of terminated for female lady teacher serving in a private school which recognized by government on the ground of she got married is obnoxious and unconstitutional and it against to public policy.

\section{CONCLUSION}

As per above study and research bring to notice that dignity of women workers and women in the society provides an exact measure for the development of society. The women represent the half the society providing them to equal opportunity and equal treatment entire societies will be destined to perform below their true potentials. Women's also raise their voice by utilizing free legal services offered by them to resolve their disputes. Not only that the government also implement all laws in effective way to protect women employees by eradicating of exploitation of labour takes place in employment will be benefited to ensure social justice in proper way.

\section{REFERENCES}

1. M P Jain “Indian Constitutional Law" pp. 1492-1498. Lexis Nexis, $8^{\text {th }}$ edn. 2018

2. Dr. J N Pandey "Constitutional Law of India" pp.41,94. Central Law Agency $56^{\text {th }}$ edn 2019

3. Dr. S C Tripathi "Women and Criminal Law, pp -20-25, Central Law Publications $2^{\text {nd }}$ edn. 2014

4. H M Seervai "Constitutional Law of India, pp.110-112, Universal Law Publication $4^{\text {th }}$ edn.2021

5. S P Sathe "Judicial Activism in India, pp.12 Oxford University Press, New Delhi, 2002

6. S.N. Misra "Labour and Industrial Laws pp.899-901, Central Law Publications $23^{\text {rd }} 2 \mathrm{dn} 2007$

7. Dr. S R Myneni “Law relating to Women pp.23-43, Asia Law House publications $4^{\text {th }}$ edn 2020

8. S K Puri “Labour and Industrial Law pp346-392, Allahabad Law Agency $11^{\text {th }}$ edn 2017

9. Dr. S K Kapoor "Human Rights Under International Law and Indian Law pp 320-336, Central law Agency,2001

10. Agarwal B D "New Road to Speedy Justice, Nyaya Deep, New Delhi Vol-V, Issue-II, April June 2002

11. Pooja $\mathrm{T}$ "Women Rights Under Indian Labour Laws- A Socio-economic Study- E-Journal, by www.legalservices.india, accessed on 2/10/2021.

12. Baxi upendra- “Access, Development and Distributive Justice-18 JII 3751976

13. Sharma, Archane "Right to Free Legal Aid and Judicial Activism, Coachin University Law Review, 1989

14. The Legal Services Authorities Act, 1987 KLJ Publications, $2^{\text {nd }}$ edn, 2019

15. R. D. Rajan “A premier on Alternative Dispute Resolution" pp.92-93 Bharathi Law Publications, new edition 2005 